\title{
På frugtbar afstand
}

\author{
Ingrid Ank
}

På afstand - Forskydninger mellem Grundtvig og Luther, Ove Korsgaard og Michael Schelde (red.), Eksistensen Akademisk, Frederiksberg 2017, 214 sider, 229 $\mathrm{kr}$.

Det er temmelig længe siden, det var comme il faut at beskrive historiens gang og udvikling som en begivenhedshistorie båret frem af enkeltpersoners temperament, kløgt og styrke (Hannibal der går med sine elefanter over alperne osv.), så længe at det vel nærmest i dag er kontroversielt at hævde, at enkeltpersoners 'person' overhovedet har nogen betydning for et samfunds udvikling og historie. Sådan som det er Francis Fukuyamas påstand i værket The Origins of Political Order fra 2011, som redaktørerne af antologien På afstand - Forskydninger mellem Grundtvig og Luther, professor Ove Korsgaard og centerleder Michael Schelde, refererer til i deres indledning. For den, der ikke er historieteoretiker, kan det ellers lyde som en påstand, der indeholder en vis mængde common sense, at enkeltpersoner også er eller kan være en medvirkende årsag til f.eks. fremkomsten og udviklingen af en ny samfundsform, visse enkeltpersoner selvfølgelig mere end andre.

Både Luther og Grundtvig er helt oplagte 'case studies' i forhold til den påstand. For selv om det er indlysende, at den upolerede bondesøn Martin Luther befandt sig i den rigtige tid på det rigtige sted, og at dette er en væsentlig del af forklaringen på, at reformationen kunne tage fart og form, så står der stadig noget tilbage, som må tilskrives, at 'Luther var Luther'. Og det samme kan siges om Grundtvig, også selv om han næppe var slået igennem på samme måde, havde det ikke været for et stærkt Tyskland, der pressede Danmark sydfra, eller for strømninger fra oplysningstiden og Den franske revolution, der gjorde det påkrævet, at danskerne fandt ud 
af, at de var danskere, og hvad det ville sige. Der manglede 'en Grundtvig' til at byde ind med svar på de spørgsmål. Og alligevel er 'Grundtvig også Grundtvig'. Andre personer end Grundtvig kunne have budt ind på opgaven med at formulere den danske folkeidentitet med et andet resultat til følge, og det gjorde de også, men uden samme vidtrækkende konsekvenser. Grundtvig og Luther er således oplagte til at afprøve Fukuyamas tese om enkeltpersoners betydning.

Men selv om redaktørerne i indledningen til bogen lægger dette an som en tese, der skal forfølges i antologiens bidrag, er det dog ikke et tydeligt og bærende spor, som alle bidragsydere forholder sig direkte til. Interessant er det derimod, at Grundtvig så at sige selv forholder sig til Fukuyamas tese, når han i Nordens Mythologi (1832) skriver, at uden Luther var der ganske givet kommet et opgør med pavekirken alligevel. Men med en anden udgang (9 f.). Grundtvig er jo netop også selv historieteoretiker, hvilket særligt den første og sidste artikel i antologien beskæftiger sig med, og er til trods for sit dybdehistoriske og universalhistoriske perspektiv altså på linje med Fukuyama i forhold til påstanden om, at enkeltpersoner har betydning for historiens udvikling. Og samtidig er han en samfundsbygger, der ved, at historien kan 'bruges til noget'. Dette er også et spor, der er tydeligt i flere af bidragene, altså at Grundtvig er i stand til at 'bruge Luther' - bruge hans tænkning, betydning og symbolværdi - i forhold til sit eget projekt.

Det spor, der nemlig er tydeligt gennemgående i alle bidrag, og som redaktørerne også lægger an til i indledningen, er naturligvis forholdet mellem de to, Luther og Grundtvig, og mellem de historiske perioder, de hver især befinder sig i. Grundtvigs Lutherreception er helt afgørende at trække frem i en dansk sammenhæng. Ikke mindst i et reformationsjubilæumsår, som har været præget af en række besynderlige diskussioner i den offentlige debat, f.eks. om hvorvidt Luther har stået fadder til 'det moderne samfund', herunder 'demokratiet' og 'det moderne selvberoende individ' (se f.eks. Stjernfelt 2017). Det har Luther selvfølgelig kun i det omfang, hans tanker blev mødt af nye tanker, herunder ikke mindst fra N.F.S. Grundtvig. Og lige så vel som man kan kalde Danmark et gennemluthersk land, er Danmark også et land, hvis samfund, identitet og kristendomsforståelse er blevet til gennem en Lutherkritik. Ikke mindst altså Grundtvigs. I forhold til denne diskussion udgør antologien et væsentligt bidrag. 
Antologier er sjældent kassesucceser for et forlag, hvilket på mange måder er en skam. Ofte lider antologier den kranke skæbne, at studerende og andre kopierer det ene kapitel, de skal bruge, og springer de andre perspektiver - og jo dermed også de indbyrdes perspektiver - over. Dermed går man som læser glip af det, som antologier kan, nemlig at lade en række perspektiver på omtrent samme emne belyse hinanden og diskutere med hinanden. Dette lykkes i stor stil i $P a ̊ a f s t a n d$, hvor en række af bidragene er tæt relaterede og dermed perspektiverer hinanden. Samtidig kan man også overveje, om der er oplagte vinkler og bidrag på det overordnede emne, 'Luther-Grundtvig', som synes at mangle. Mere herom nedenfor.

\section{Om de enkelte bidrag}

$P a ̊ a f s t a n d$ indeholder otte bidrag og perspektiver på Luther og Grundtvig og forholdet imellem dem. Lektor Anders Holm redegør i den første artikel, "Grundtvigs Lutherbilleder", for, hvordan det lykkes Grundtvig, i kraft af ideer hentet fra romantikken, at skrive både Luther og sig selv ind i en 'universalhistorie', hvori modsætninger imellem dem viser sig som vigtige delelementer i et samlet historisk forløb. Dette gør det ifølge Holm muligt for Grundtvig at fastholde 'ideen om reformationen' med Luther som reformationens begyndelsespunkt samtidig med, at reformationens fortsættelse for Grundtvig nødvendigvis må tage form som et opgør med Luther. Kritikken af Luther bliver så at sige af Grundtvig fortolket som 'luthersk', og han formår derigennem at kritisere både det grund-lutherske Sola scriptura-begreb (og ikke mindst følgerne af det i form af den rationalistiske teologi på Grundtvigs egen tid) og den statskirke-religion og det kontrolsamfund, der blev den politiske konsekvens af Luthers opgør med pavemagten - samtidig med at han skriver sig selv ind i historien som Luthers efterfølger og arvtager.

Lektor Hans Raun Iversens og professor Ove Kaj Pedersens "Teologi og politik bag individets opkomst - Luthers og Grundtvigs bidrag" havde måske haft gavn af ikke at skulle presses ind i en artikelform, idet der forekommer at være stof og ansatser nok til en hel bog. Hovedanliggendet er beskrivelsen af fremkosten af 'individet', der på Luthers tid ikke eksisterede ("individet respekteredes ikke, for det eksisterede ikke” (48)) og på Grundtvigs tid var ved at tage form. Men til trods for, at individets 
(begyndende) fremkomst ligger mellem Luther og Grundtvig, lægges der i artiklen særlig vægt på ligheder mellem Luther og Grundtvig. Begge kaldes "før-sekulariserede teologer, for hvem alt er skabt og opretholdes af Gud" (37), begge beskrives samtidig som politiske teologer, hvis hovedærinde er at afvæbne kirken og gejstligheden og centralisere magten hos den verdslige øvrighed. Begge beskrives også som "bibelkristne”, hvis samfunds-, politik- og historieforståelse grundlæggende bygger på Bibelen samtidig med, at de begge ville have afvist at drive politik på bestemte bibeltekster (38). Pointen med særligt at fremhæve ligheder mellem Luther og Grundtvig er at understrege kontinuiteten mellem det bibelske begyndelsespunkt, hvad angår ligheden mellem mennesker - som det f.eks. udtrykkes i Galaterbrevet 3,28 - og det moderne sekulariserede begreb om det frie, ukrænkelige individ. Selv om Grundtvig således lever og tænker $i$ en anden tid end Luther, har forestillingen om individet hos begge sit afsæt i tanken om den enkeltes frihed i forhold til evangeliets modtagelse (45). Vejen fra Paulus over Luther til Grundtvig og frem til det moderne sekulære individ udgør selvfølgelig ikke en lige linje, som kan beskrives uden mellemregninger og afstikkere, og sådan fremstiller forfatterne det heller ikke, hvilket medvirker til at gøre artiklen noget kompakt.

Mere overskuelig er professor Ove Korsgaards artikel, "Luther og Grundtvig - Profeter for territorialstatens og nationalstatens legitimitetsprincip", der demonstrerer den lighed mellem Luther og Grundtvig, at de begge indtager positionen som 'profet' eller 'politisk tænker', der leverer den ideologiske legitimitet i forhold til en ny statsform, hhv. territorialstaten og nationalstaten. Luther giver fyrsterne den teologiske legitimitet til at bryde med den transnationale pavemagt, og Grundtvig opbygger og puster til en folkeidentitet, der gør landegrænser til markører af 'meget mere' end blot der, hvor en given konges magt går til. Og skaber dermed det identitetsmæssige grundlag for folkestyret. Korsgaard viser således, hvorledes Luther og Grundtvig som 'profetiske figurer' har lignende funktioner i hver deres tid, samtidig med at Grundtvigs anliggende netop er et opgør med Luthers 'territorialstat', jf. også Anders Holms artikel. Korsgaard går afslutningsvist skridtet videre i forhold til vores egen tid og rejser spørgsmålet om legitimitet, hvad angår fremtidens statsform og i forhold til det nutidige og fremtidige europæiske samarbejde.

De to følgende artikler af hhv. professor Ingrid Markussen og sognepræst Kim Arne Pedersen repræsenterer i en vis forstand to perspektiver 
på samme emne, nemlig 'hjemmet' og 'hjemmets funktion og betydning', herunder spørgsmålet om kønsroller og børneopdragelse. Markussen baserer i artiklen "N.F.S. Grundtvig og den lutherske hustavle" sine hovedpointer på en læsning af en ph.d.-afhandling af Ole Nyborg (2013), i hvilken han har krydsanalyseret 1.400 prædikenmanuskripter fra Grundtvigs hånd med fokus på udvalgte begreber. Ifølge Markussen viser prædikenanalyserne, at Grundtvig er langt mere påvirket af den patriarkalske tænkning, som kommer til udtryk i "den lutherske hustavle", end hidtil antaget (bl.a. fordi Grundtvig aldrig nævner eller beskæftiger sig med hustavlen), idet prædikerne viser "kærlighedens udspring hos manden/faderen" (98) og dermed gør kvinder (og børn) til modtagende og skyldige i lydighed og underkastelse. Hermed viser der sig en anden side af Grundtvig end den, vi f.eks. møder i hans skoleskrifter og hans frihedstanker. Som Markussen selv er inde på (95), kan der dog ligge en problematik i, at denne 'patriarkalske Grundtvig' udelukkende tolkes ud af prædikentekster. Hun henviser dog til, at der er tale om et studie af en temmelig omfattende tekstmængde, og at der derfor må være belæg for at hævde, at analysen viser et spor i Grundtvigs tænkning. Alligevel kan man vel også hævde, at det er forventeligt netop i prædikenen at støde på forestillingen om, at kærligheden har sit udspring hos "Gud Fader", og at dette vel ikke helt kan overføres til, at Grundtvig er på linje med Luthers opfattelse af husfaderen som husets og familiens overordnede?

Hos Kim Arne Pedersen, i artiklen "Husstand, hjem, asyl og børnehjem”, bliver konklusionen mht. Grundtvigs syn på familie, køn og hjem da også lidt en anden. Fokus er ikke hos Pedersen på hustavletanken, men på hhv. Grundtvigs læsning af Luthers Genesiskommentar og på en analyse af det borgerlige ideal om hjemmet og kvindens rolle, som vokser frem på Grundtvigs tid. Grundtvig er i princippet fuldt på linje med Luther, hvad angår forestillingen om det ideelle familieforhold som en afspejling af Paradislivet. Dette understreges yderligere af, at hjemmet - og dermed kvinden - på Grundtvigs tid har fået en anden betydning og funktion, idet hjemmet nu er blevet et sted, manden forlader for at gå på arbejde, og ikke - som på Luthers tid - mandens, kvindens og den øvrige husstands fælles arbejdsplads med manden som overhoved. Opfattelsen af kvindens plads i hjemmet kontrasteres dog - ifølge Pedersen - af Grundtvigs modstand mod tvang og erkendelse af, at 'paradisiske tilstande' ikke lader sig gennemtrumfe. Pedersen peger på, at en vej ud af hjemmet for 
kvinden på Grundtvigs tid f.eks. blev det almenvelgørende arbejde med at etablere asyler for forældreløse børn i forhold til hvilke, tankerne om, hvad 'et rigtigt hjem' er, satte sine spor. Pedersen peger endvidere på, at de grundtvigsk-inspirerede børnehjem - det eneste eksempel på en grundtvigsk diakonal/social indsats (128) - er et indtil videre underbelyst emne.

Spørgsmålet om køn er også på spil i sognepræst Synnøve Sakura Heggems artikel, "Maria i Luthers og Grundtvigs optikk - Paradoksal forvaltning av Maria-tradisjoner", der indledes med et citat af den feministiske filosof og teolog Mary Daly: "If God is male, male is God" (159). Heggem pointerer, at når det maskuline favoriseres inden for teologien og $\mathrm{i}$ den liturgiske tradition, smitter det af på kønsopfattelserne i samfundet i øvrigt. Heggem understreger samtidig, at hverken Luther eller Grundtvig skal have ansvaret for, at Mariatraditionen stort set er forsvundet inden for den protestantiske kirke. Luther afskrev hende ikke, men understregede hendes "nichtigkeit" (165): Sådan som et menneske modtager Guds nåde, modtager Maria Guds barn, nemlig aldeles ufortjent. Hos Grundtvig, derimod, er Maria ikke intet, men et billede på og udtryk for mennesket, der svarer og kan svare Gud, idet Heggem også fremhæver, at hos Grundtvig - i modsætning til hos Luther - skaber Gud ikke ud af intet, men ud af kærlighed (165). Grundtvig har altså ifølge Heggem potentialet til at give Mariatraditionen en ny betydning, der både gør op med den katolske understregning af hendes renhed (som ifølge Simone de Beauvoir og andre har forvrænget synet på kvinden igennem århundreder) og med Luthers betoning af hendes 'intethed'. Således forekommer det også Heggem paradoksalt (jf. artiklens overskrift), at Mariatraditionen i stedet er forsvundet helt ud af liturgien og den protestantiske teologi i Danmark. Heggems artikel kan således - som Pedersens - læses som en replik til Markussens, idet der viser sig aspekter af den grundtvigske teologi, som udfordrer den patriarkalske struktur, Markussen finder i prædikerne.

Forud for Heggems artikel går en artikel af ph.d. Uffe Jonas, "Målet, som Guds engle tale' - Om Luther, Grundtvig og den syngende kirke", der omhandler musikkens betydning hos både Luther og Grundtvig. I artiklen fremhæves Luthers understregning af musikkens og sangens betydning som en gave fra Gud og som en 'himmelsk dans'. Musikken bliver således det medium, i hvilket jord og himmel smelter sammen, og det hellige træder frem. Artiklen forekommer sine steder at være mere 'Grundtvig-inspireret' end en egentlig læsning af Grundtvig, eller i hvert 
fald savnes der dokumentation for, hvorledes Grundtvig ser på og overtager/omtolker Luthers tanker, hvad angår musikken. Jonas problematiserer - gennem en læsning af Johannes Værge (2011) - hvorledes den juridiskorienterede dogmatik satte sig igennem med Tertullian og udsatte kristendommen for en forvridning, der gjorde den egnet som statsreligion og som synd-bod-og-straf-system på bekostning af en poetisk-musikalsk kosmologisk teologi, som Luther ikke, til trods for sin begejstring for musikken, genetablerede. Det var derimod Grundtvigs ærinde ifølge Jonas. Men som nævnt forekommer det lidt uklart, hvorvidt det er Grundtvig eller Jonas, der har et anliggende - f.eks. i citater som dette: "Det åndelige gudsnærvær er blevet erstattet af den metodiske teologiske rekonstruktion, den kosmiske Kristus af den historiske Jesus. Den sang, som engang var frisk og ny, er med tiden blevet reduceret til et stadigt svagere og blegere ekko" (152).

Antologiens afsluttende artikel, "Kirkehistoriske adaption - Om Grundtvig, (Grundtvigs) Luther og kulturel evolution" af lektor Katrine Frøkjær Baunvig, er godt placeret som bogens sidste, idet den som Holms artikel i begyndelsen forholder sig til spørgsmålet om historiesyn. Ved at læse Grundtvig i lyset af religionsvidenskabsmanden Roy A. Rappaport peger Frøkjær på, at Grundtvig var i stand til at aflæse krisetegn i sin samtids tros- og kirkeliv, der gjorde det nødvendigt for ham at gå radikalt til værks i sit opgør med den lutherske tradition og med Luthers og de lutherskes påstand om, at Bibelen er kirkens fundament. Til trods for sin orientering mod menighedens fællesskab repræsenterer Grundtvig således med sit opgør med det bibelske tekstfokus for Frøkjær i virkeligheden mere nutiden end sin samtid, idet Grundtvig dermed åbner vejen for 'den personligt og individuelt orienterede troende', som vi kender fra vores tid. Frøkjær hævder endda i sin indledning, at Grundtvig dermed spiller en større rolle i vores nutid, end han gjorde i sin egen (196).

\section{En frugtbar afstand mellem Luther og Grundtvig}

$P a ̊ a f s t a n d$ fungerer godt som en samlet 'pakke', hvor bidragene både perspektiver og kritiserer hinanden. Samlet set når antologien omkring Grundtvig og Luther som hhv. politiske samfundstænkere, pædagogiske tænkere, teologer og præster og viser, hvordan Grundtvig på alle disse 
områder står både i gæld til og i et opgør med Luther. Det bliver ydermere tydeligt, som det var nævnt i indledningen, at Grundtvigs fortolkning af og delvise opgør med Luther har sat sig sine tydelige spor. Vi er ikke kun efterladt med en luthersk arv, men også, og ikke mindst, med et grundtvigsk Lutheropgør som arv. Som nævnt forfølges Fukuyamas tese om visse enkeltpersoners betydning for historiens gang og samfundsudviklingen ikke eksplicit i alle bidrag; alligevel kan man med antologien konkludere, at netop Luther og Grundtvig har haft så stor betydning for både kirke-, skole- og samfundsudviklingen, at den nærmest ikke lader sig overvurdere. Ydermere kan man føje til Fukuyamas tese, at der findes 'visse enkeltpersoner', som har haft så stor betydning for 'visse enkeltpersoner', at de slet ikke ville have været den samme uden: Grundtvig er på mange måder utænkelig uden Luther. Titlen $P a ̊$ afstand refererer så at sige ikke blot til den tidsmæssige afstand på 300 år mellem Luther og Grundtvig, der selvfølgelig betyder, at vi må forholde os til dem på to meget forskellige historiske baggrunde. Men også til den frugtbare afstand, der efterhånden opstår hos Grundtvig i hans forhold til Luther, og som gør det muligt for ham at kritisere Luther konstruktivt.

Afslutningsvist må man spørge, om der er noget, der mangler i antologien. Det er klart, at man altid vil kunne pege på yderligere aspekter, der kunne have været behandlet, men i hvert fald to vinkler trænger sig på. Det ene er en læsning af Grundtvigs salmedigtning set i forhold til Luthers, herunder Grundtvigs Luthergendigtning. Dette væsentlige kapitel i Grundtvigs fortolkning af og opgør med Luther er fraværende i antologien. Et sådant bidrag ville også have styrket det teologiske fokus i antologien, som overvejende hælder til det samfundsvidenskabelige, hvilket afsættet hos Fukuyama selvfølgelig også lægger op til. Det andet, man 'mangler', er en undersøgelse af den historiske udvikling inden for det retlige felt i tiden mellem Luther og Grundtvig og af deres positioner og indflydelser i forhold hertil. Både Korsgaard og Holm henviser i deres artikler til et mundtligt oplæg af professor Lisbeth Christoffersen, holdt på det seminar, som har dannet afsæt for antologien. Det ville have været fint, om vi andre ikke havde måttet nøjes med at gætte os til indholdet af dette mundtlige oplæg, men havde fået bidraget med som artikel i antologien.

Disse indvendinger til trods er antologien et perspektivrigt og grundigt bidrag til læsningen af Grundtvigs fortolkning af og opgør med Luther og 
dermed til en forståelse af de forskydninger mellem de to, som udgør vores grundtvigsk-lutherske arv.

\section{Bibliografi}

Verker af Grundtvig

- (1832) Nordens Mythologi eller Sindbilled-Sprog, København, J.H. Schubothes Boghandling.

Verker af andre forfattere

Daly, Mary (1973/1986), Beyond God the Father. Towards a Philosophy of Women's Liberation, UK, The Womens Press.

Fukuyama, Francis (2011), The Origins of Political Order, New York, Farrar, Straus and Giroux.

Nyborg, Ole (2013), Grundtvig og karligheden. Karlighedsforståelsen i N.F.S. Grundtvigs pradikener, København, Det Teologiske Fakultet.

Rappaport, Roy (1999), Ritual and Religion in the Making of Humanity, Cambridge, Cambridge University Press.

Stjernfelt, Frederik (2017), Syv myter om Luther, København, Gyldendal.

Værge, Johannes (2011), Det betroede menneske. Opgor med forvreden kristendom, Frederiksberg, Anis. 